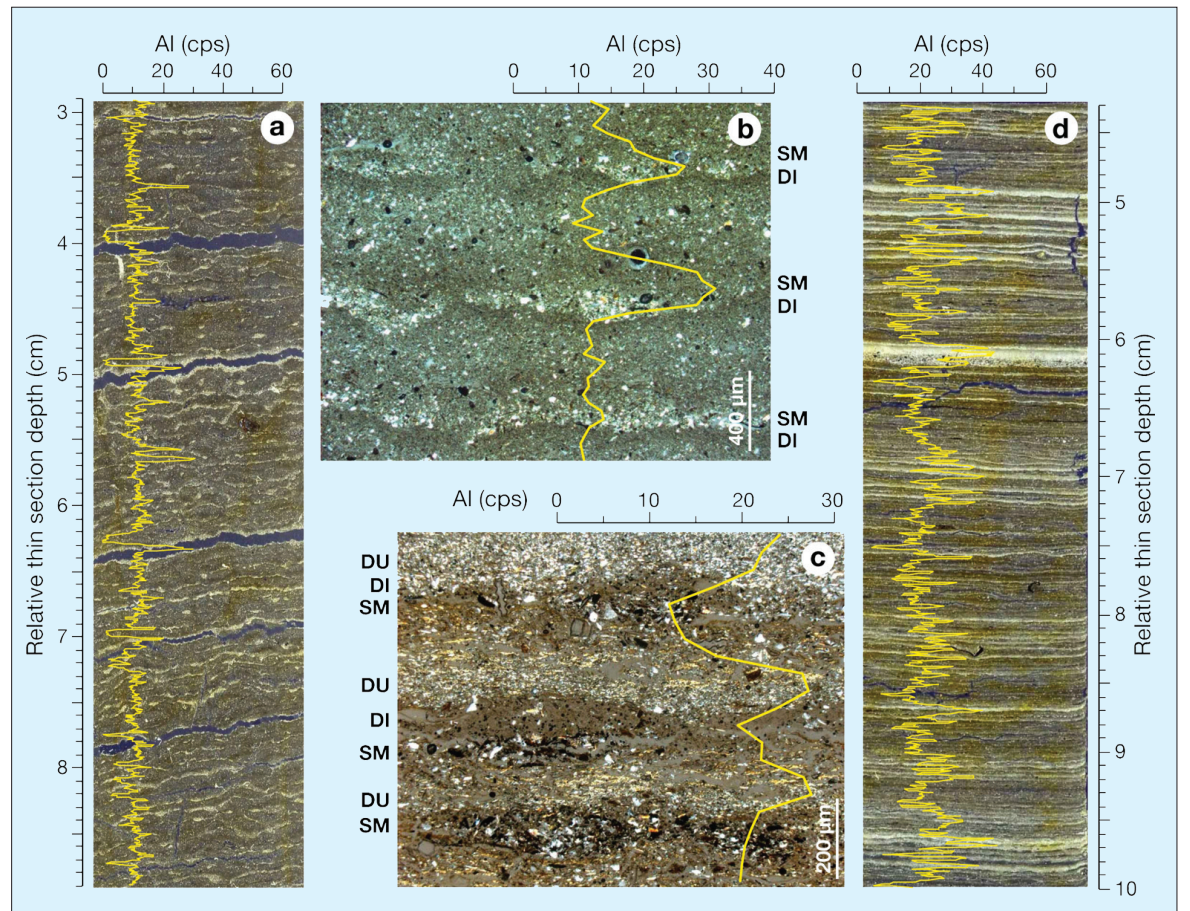

Figure 3: Comparison of modern $(\boldsymbol{a}, \boldsymbol{b})$ and early Holocene $(\boldsymbol{c}, \boldsymbol{d})$ micro-facies of varves from Lake Sihailongwan, China. a) and d) show scanned thin sections (polarized light) and superposed Al-profiles as proxy for siliciclastic detritus; note the pronounced inter-annual variability in the occurrence of dust layers (light colors); b) and c) show thin section images (polarized light) showing differences in seasonal sub-layer deposition and superimposed Al-profiles: DU - dust layer; DI - diatom layer; SM - snow melt layer. Fine-grained detrital layers indicate seasons of dust deposition and can therefore provide a record of dust transport from periods without human impact.

\section{Note}

Varve and micro-XRF Fe data from Lake Meerfelder Maar are available from the NOAA/WDC Paleo archive: ftp://ftp.ncdc.noaa.gov/pub/ data/paleo/paleolimnology/europe/germany/ meerfelder-maar2008.txt

\section{References}

Brauer, A., Haug, G.H., Dulski, P., Sigman, D.M. and Negendank, J.F.W. 2008a: An abrupt wind shift in Western Europe at the onset of the Younger Dryas cold period, Nature Geoscience, 1: 520-523.

Brauer, A., Mangili, C., Moscariello, A. and Witt, A., 2008b: Palaeoclimatic implications from micro-facies data of a 5900 varve time series from the Pianico interglacial sediment record, Southern Alps, $\mathrm{Pa}-$ laeogeography Palaeoclimatology, Palaeoecology, 259: 121-135.

Mangili, C., Brauer, A., Moscariello, A. and Naumann, R., 2005: Microfacies of detrital event layers deposited in Quaternary varved lake sediments of the Piànico-Sèllere Basin (northern Italy), Sedimentology, 52: 927-943

Mingram, J., Allen, J.R.M., Brüchmann, C., Liu, J., Luo, X., Negendank, J.F.W., Nowaczyk N. and Schettler, G., 2004: Maar- and crater lakes of the Long Gang Volcanic Field (N.E. China) - overview, laminated sediments, and vegetation history of the last 900 years, Quaternary International, 123-125: 135-147.

Schettler, G., Mingram, J., Liu, Q., Stebich M. and Dulski, P., 2006: EastAsian monsoon variability between 15000 and 2000 cal. yr BP recorded in varved sediments of Lake Sihailongwan (northeastern China, Long Gang volcanic field), The Holocene, 16(8): 1043-1057.

For full references please consult:

www.pages-igbp.org/products/newsletters/ref2009_3.htm

\title{
Fourier transform infrared spectroscopy: Rapid, quantitative analysis of biogeochemical properties of lake sediments
}

Peter Rosén ${ }^{1}$, H. Vogel ${ }^{2}$, L. Cunningham ${ }^{1,3}$, N. Reuss ${ }^{4}$, D. Conley and P. Persson ${ }^{6}$

${ }^{1}$ Climate Impacts Research Centre, Umeå University, Abisko, Sweden; peter.rosen@emg.umu.se

${ }^{2}$ Institute for Geology and Mineralogy, University of Cologne, Germany; ${ }^{3}$ Department of Geography and Geosciences, University of St Andrews, Scotland; ${ }^{4}$ Freshwater Biological Laboratory, University of Copenhagen, Hillerød, Denmark; ${ }^{5}$ GeoBiosphere Science Centre, Quaternary Sciences, Lund University, Sweden; ${ }^{6}$ Department of Chemistry, Umeå University, Sweden

\section{FTIRS analysis of small sediment quantities can provide fast, inexpensive and high-resolution records of organic and inorganic carbon, nitrogen and biogenic silica that are essential for detailed paleoclimate and environmental reconstructions in long sediment records.}

Continuous paleoclimate records from the continental realm covering several climatic cycles are increasingly recognized as important archives of environmental responses to climatic change. Given anthropogenic global warming, this information is particularly crucial for the understanding of natural climate variability. Over the past decade, the recovery of long sedimentary records from terrestrial sites and, in particular, large and ancient lakes, has been made possible by the International Continental Drilling Program (ICDP) and associated partners. The most recent example is Lake El'gygytgyn, where the longest (>300 m, 3.6 Ma) and probably most continuous terrestrial paleoclimate archive has been recovered during the spring 2009 deep drilling campaign. In order to extract information on climatic and environmental change from these long records at a high temporal resolution, fast, cost-efficient and, preferably, non-destructive methods are required. X-ray fluorescence scanners and multi-sensor core loggers can provide such highly resolved, qualitative and semi-quantitative information on the inorganic geochemistry, mineralogy, and magnetic properties of sediments. Non-destructive methods providing quantitative information on biogeochemical properties, however, have not been available until present. Within the initial Lake El'gygytgyn deep drilling project, and preliminary studies for potential deep drilling projects at Lake Ohrid and Pingualuit Crater Lake, we tested the potential of Fourier transform infrared spectroscopy (FTIRS) as analytical method for the quantitative determination of bio- geochemical properties. The great potential of the FTIRS technique comes from the large amount of information on minerogenic and organic substances provided by the FTIR spectra. Most importantly, it is a rapid, cost-saving technique, which only requires very small amounts $(0.01 \mathrm{~g}$ dry weight) of sample material.

\section{Analytical background and principles of FTIRS}

The basic principle of the FTIRS technique is that infrared radiation stimulates molecular vibrations and, as a consequence of the quantum mechanical behavior, this radiation is absorbed at specific wavenumbers. Major changes in organic and inorganic properties present in sediment can therefore be qualitatively identified from the FTIR spectra. For example, the band 


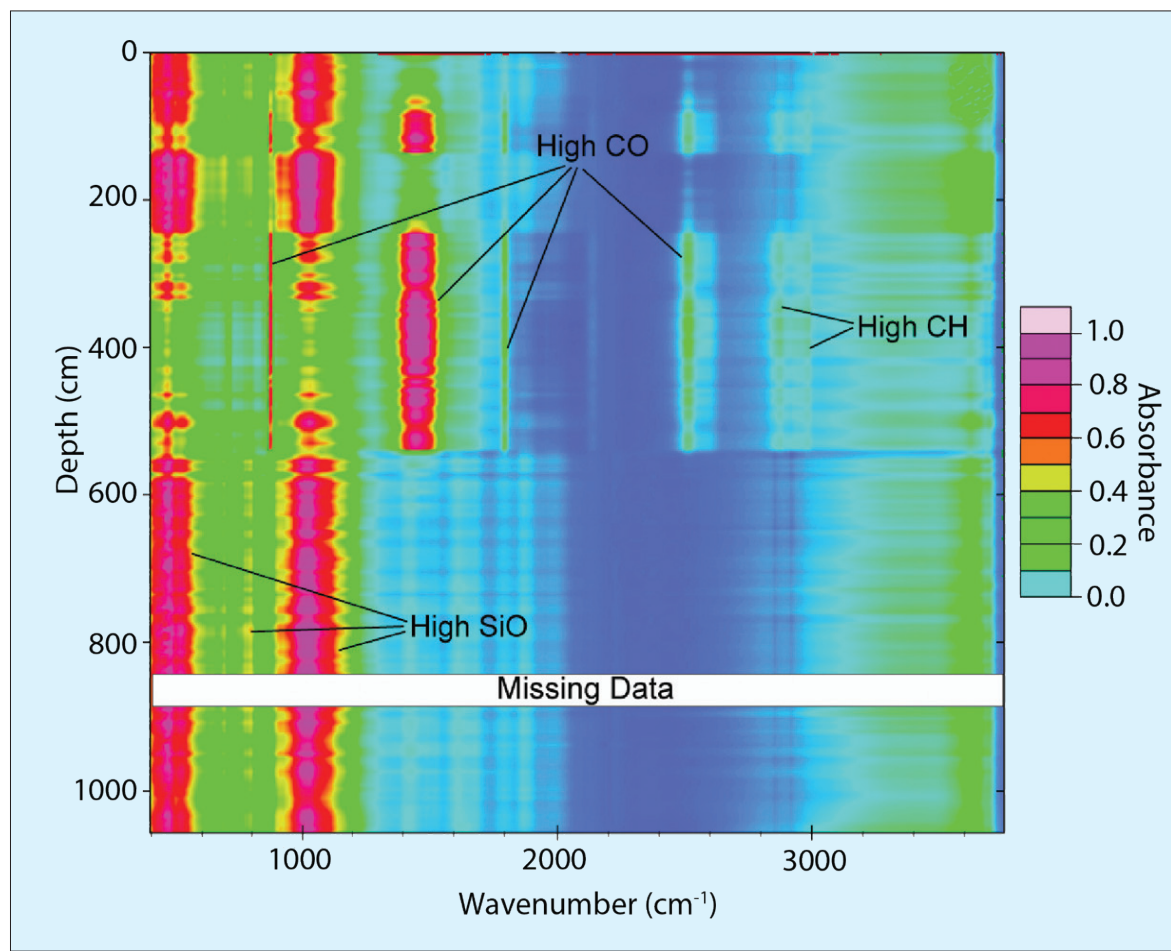

Figure 1: 2D plot of FTIR spectra from sediment core Lz1120 (Lake Ohrid, Albania/Macedonia). Wavenumbers are displayed on the x-axis, sediment depths are shown on the $y$-axis, and absorbance is indicated by a color chart with red/violet indicating highest and blue indicating lowest absorbance. Absorption bands for C-H stretching in organic carbon, C-O stretching in inorganic carbon and Si-O stretching in silica are indicated in the graph. The sediments show large changes within these components (from Vogel et al., 2008, with permission from Springer Verlag).

between 2850 and $2950 \mathrm{~cm}^{-1}$ is due to $\mathrm{C}-\mathrm{H}$ vibrations in $-\mathrm{CH}_{3},-\mathrm{CH}_{2}$ and $-\mathrm{CH}$ groups of organic compounds. Bands centered on

$1715 \mathrm{~cm}^{-1}$ are assigned to the stretching vibration of the $-\mathrm{C}=\mathrm{O}$ group of fatty acids (Mecozzi and Pietrantonio, 2006). Carbon-

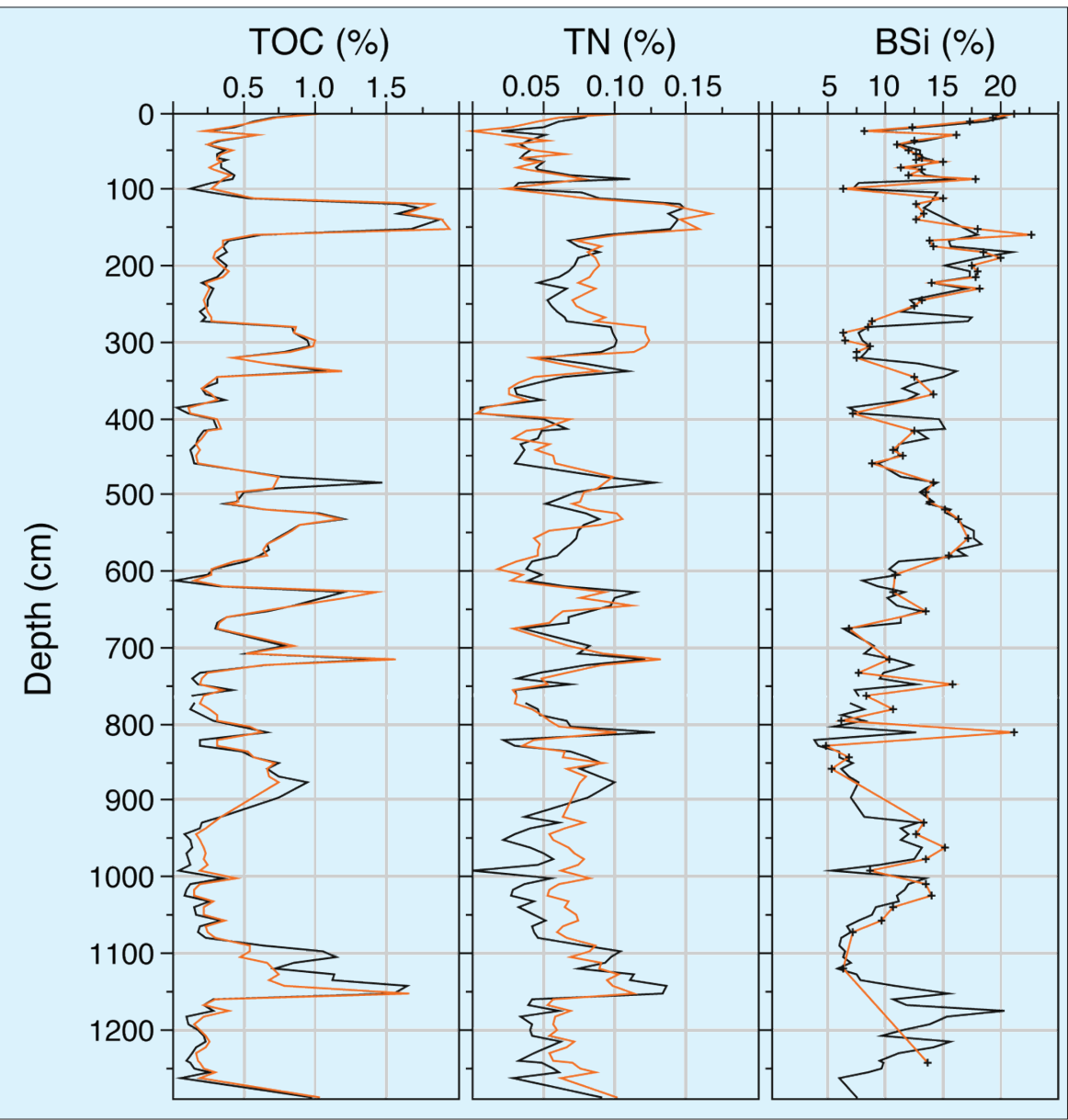

Figure 2: Downcore plot of total organic carbon (TOC), total nitrogen (TN) and biogenic silica (BSi) within sediment core PG1351 from Lake El'gygytgyn (northeastern Siberia), measured with conventional (orange line) and inferred (black line) techniques using FTIRS. Due to the lower number of conventionally measured BSi concentrations, these samples are identified by crosses (from Vogel et al., 2008, with permission from Springer Verlag). ate in calcite minerals has important $\mathrm{C}-\mathrm{O}$ molecular vibrations around 710,875 , 1425, 1460, 1800 and $2500 \mathrm{~cm}^{-1}$ (White, 1974; Mecozzi and Pietrantonio, 2006; Rosén et al., 2009) and SiO in biogenic silica has an important absorbance maximum at $1100 \mathrm{~cm}^{-1}$ (Stehfest et al., 2005; Rosén et al., 2009). FTIRS can thus provide information on a wide range of organic and minerogenic components, e.g., carbohydrates, humic substances, silicates and carbonates (Calace et al., 1999; Stehfest et al., 2005; Mecozzi and Pietrantonio, 2006; Fig. 1). This information is of particular interest for paleolimnological studies because lake sediments are commonly composed of a mixture of various organic and minerogenic compounds originating from the fossilization of tissues and skeletons of aquatic organisms and from the erosion of lake catchment soils. Absorbance in FTIR spectra from the mid-infrared region directly relates to the concentration of specific compounds, and thus many organic and minerogenic sedimentary components can also be quantified by their own "fingerprint-like" infrared spectra. To obtain quantitative information using FTIRS, concentrations of sedimentary components measured by conventional techniques are regressed against the FTIR spectra using partial least square regression (PLS). A PLS loading plot can be compared with reference spectra of the pure component of interest, thus ensuring that the correct wavenumbers are used by the model (Rosén et al., 2009). So far, quantitative models for total organic carbon (TOC), total inorganic carbon (TIC), total nitrogen (TN), and biogenic silica (BSi) have been developed and successfully applied to lake sediments from different climatic settings (Vogel et al., 2008; Rosén et al., 2009). These promising results confirm the great potential of FTIRS as a powerful tool in high-resolution, multi-proxy paleolimnological studies.

\section{Potential, limitations and examples}

Interpretation of FTIR spectra can be complicated by overlapping peaks and bands that can result from the mixture of a large number of components in lake sediments. As a consequence, it is most likely that only the most common components or those with narrow absorption bands can be assessed quantitatively using FTIRS. For longer sediment records to be analyzed, for example those of ICDP deep drilling projects, with cores exceeding several hundred meters in length, the creation of a site-specific internal calibration is recommended. This technique has already been 
applied to sediments of lakes El'gygytgyn, Siberia, Ohrid, Albania/Macedonia and Pingualuit, Canada (Vogel et al., 2008; Rosén et al., 2009). As shown in Figure 2 , FTIRS-inferred TOC, TN and BSi are plotted against values using conventional techniques and the results show a close agreement (Vogel et al., 2008). Although the results look promising, we should keep in mind that this quantitative approach has only been tested on a few lakes and we therefore recommend that some FTIRSinferred values are cross-checked against "conventionally" measured values. With respect to the Lake El'gygytgyn sediment record, FTIRS-inferred BSi concentrations have become one of the most important proxy indicators for assessing past climatic and environmental change at fairly highresolution back to $340 \mathrm{ka}$. In addition to quantitative assessment of biogeochemical properties, FTIRS has also been used to assess past changes in tree line and to infer lake water TOC (Rosén and Persson, 2006). After samples have been freezedried, ground and mixed with potassium bromide, up to 300 samples per day can be analyzed using FTIRS, which is about ten times faster compared to leaching methods (e.g., Müller and Schneider, 1993) commonly used for the determination of BSi concentrations, clearly demonstrating the advantages of FTIRS over conventional methods.

\section{Other research areas and future applications}

FTIRS is widely used in both research and industry as a reliable technique for the measurement and quality control of food and pharmaceuticals. The technique is also used in soil science to complete studies on molecular-level processes at mineral, organic, and bacterial surfaces that influence the biogeochemical cycles of elements (Schnürer et al., 2006). In recent years, the development of the FTIRS microscopy technique makes it also possible to assess specific spectra of components identified with the help of a microscope. One such example is demonstrated in Rosén et al. (2009) where spectra from single diatom valves were assessed. Thanks to the continuous technological development and improvement of FTIR spectroscopy, potential applications of the technique also continue to increase. Considering the variety of applications presented in this newsletter, we encourage more researchers to further develop this method for potential application in marine/ocean or lake sediment science.

\section{References}

Mecozzi, M. and Pietrantonio, E., 2006: Carbohydrates proteins and lipids in fulvic and humic acids of sediments and its relationships with mucilaginous aggregates in the Italian seas, Marine Chemistry, 101: 27-39.

Rosén, P. and Persson, P., 2006: Fourier-transform infrared spectroscopy (FTIRS), a new method to infer past changes in tree-line position and TOC using lake sediment, Journal of Paleolimnology, 35 : 913-923

Rosén, P., Vogel, H., Cunningham, L., Reuss, N., Conley, D. and Persson, P., 2009: Fourier transform infrared spectroscopy, a new method for rapid determination of total organic and inorganic carbon and opal concentration in lake sediments, Journal of Paleolimnology, DOl: 10.1007/s10933-009-9329-4.

Stehfest, K., Toepel, J. and Wilhelm, C., 2005: The application of microFTIR spectroscopy to analyze nutrient stress-related changes in biomass composition of phytoplankton algae, Plant Physiology and Biochemistry, 43: 717-726.

Vogel, H., Rosén, P., Wagner, B., Melles, M. and Persson, P., 2008: Fourier transform infrared spectroscopy, a new cost-effective tool for quantitative analysis of biogeochemical properties in long sediment records, Journal of Paleolimnology, 40: 689-702.

For full references please consult:

www.pages-igbp.org/products/newsletters/ref2009_3.html

\title{
Stable isotopes in chitinous fossils of aquatic invertebrates
}

\author{
Oliver Heiri', M.J. Wooller ${ }^{2}$, M. van Hardenbroek ${ }^{1}$ and Y.V. WANG ${ }^{2,3}$ \\ 'Laboratory of Palaeobotany and Palynology, Utrecht University, The Netherlands; O.M.Heiri@uu.nl \\ ${ }^{2}$ Alaska Stable Isotope Facility, University of Alaska Fairbanks, USA; ${ }^{3}$ Current address: Institute of Geosciences, University of Kiel, Germany

\section{Current stable isotope techniques permit the development of new approaches for reconstructing past climate and aquatic food webs based on chitinous invertebrate fossils from lake sediments.}

Chitin is one of the most abundant macromolecules in the biosphere. It can be found in the cuticles of most invertebrates (Cauchie, 2002) and especially in exoskeletons of insects and crustaceans, where elastic chitin rods are typically embedded in and cross-linked with a matrix of proteins (Nation, 2002; Raabe et al., 2005). Organic invertebrate remains, such as exoskeleton plates, mouthparts, or sclerotized resting stages, preserve well in lake sediments (Fig. 1). After the initial decomposition of degradable material, these structures can remain chemically stable for tens of thousands of years (Stankiewicz et al., 1997a) and, in exceptional cases, chitin may even preserve for millions of years in sediments (Stankiewicz et al., 1997b).

Stable isotope analysis of organic material produced in lakes and their surroundings provides information on past climate and ecosystem processes within lakes (e.g., Meyers and Lallier-Vergès,
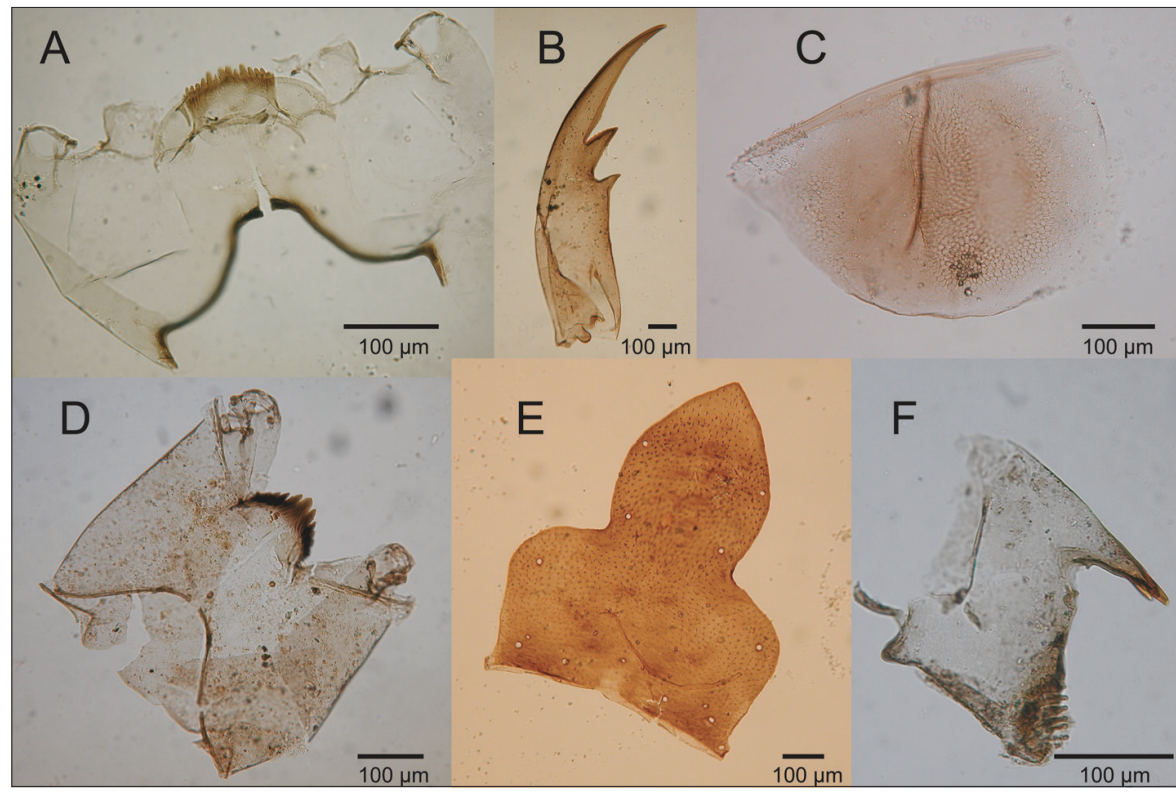

Figure 1: Examples of chitinous fossils produced in lakes and preserved in lake sediments: Head capsules of chironomid larvae (A, Polypedilum nubeculosum-type; $\boldsymbol{D}$, Cricotopus), mandibles of larvae of other aquatic insects ( $\boldsymbol{B}$, Megaloptera; $\boldsymbol{F}$, Ephemeroptera), a resting egg (ephippium) of a water flea (C, Cladocera), and a head capsule part (clypeus) of a caddisfly larva (E, Trichoptera). 


\section{Full Reference List:}

Calace, N., Capolei, M., Lucchese, M. and Petronio, B.M., 1999: The structural composition of humic compounds as indicator of organic carbon sources, Talanta, 49: 277-284.

Mecozzi, M. and Pietrantonio, E., 2006: Carbohydrates proteins and lipids in fulvic and humic acids of sediments and its relationships with mucilaginous aggregates in the Italian seas, Marine Chemistry, 101: 27-39.

Müller, P.J. and Schneider, J., 1993: An automated leaching method for the determination of opal in sediments and particulate matter, Deep-Sea Research, 40: 425-444.

Rosén, P. and Persson, P., 2006: Fourier-transform infrared spectroscopy (FTIRS), a new method to infer past changes in tree-line position and TOC using lake sediment, Journal of Paleolimnology, 35: 913-923.

Rosén, P., Vogel, H., Cunningham, L., Reuss, N., Conley, D. and Persson, P., 2009: Fourier transform infrared spectroscopy, a new method for rapid determination of total organic and inorganic carbon and opal concentration in lake sediments, Journal of Paleolimnology, DOI: 10.1007/s10933-009-9329-4.

Schnürer, Y., Persson, P., Nilsson, M., Nordgren, A. and Giesler, R., 2006: Effects of surface sorption on microbial degradation of glyphosate, Environmental Science and technology, 40: 4145-4150.

Stehfest, K., Toepel, J. and Wilhelm, C., 2005: The application of micro-FTIR spectroscopy to analyze nutrient stress-related changes in biomass composition of phytoplankton algae, Plant Physiology and Biochemistry, 43: 717-726.

Vogel, H., Rosén, P., Wagner, B., Melles, M. and Persson, P., 2008: Fourier transform infrared spectroscopy, a new cost-effective tool for quantitative analysis of biogeochemical properties in long sediment records, Journal of Paleolimnology, 40: 689-702.

White, W.B., 1974: The carbonate minerals. In: Farmer, V.C. (Ed.), The infrared spectra of minerals, Mineralogical Society Monograph 4: 227-242 p. 